\title{
Association between proton pump inhibitor use and spontaneous bacterial peritonitis in cirrhotic patients with ascites
}

\author{
Mélissa Ratelle B Pharm $\mathrm{MSc}^{1}$, Sylvie Perreault B Pharm $\mathrm{PhD}^{2}$, \\ Jean-Pierre Villeneuve MD³, Lydjie Tremblay B Pharm MSc ${ }^{1,2}$
}

\begin{abstract}
M Ratelle, S Perreault, J-P Villeneuve, L Tremblay. Association between proton pump inhibitor use and spontaneous bacterial peritonitis in cirrhotic patients with ascites. Can J Gastroenterol Hepatol 2014;28(6):330-334.
\end{abstract}

BACKGROUND: There are data suggesting a link between proton pump inhibitor (PPI) use and the development of spontaneous bacterial peritonitis (SBP) in cirrhotic patients with ascites; however, these data are controversial.

OBJECTIVE: To assess whether the use of PPIs in cirrhotic patients with ascites is associated with an increased risk for SBP.

METHODS: A retrospective case-control study (June 2004 to June 2010) was conducted at the Centre Hospitalier de l'Université de Montréal in Montreal, Quebec. Fifty-one cirrhotic patients admitted with paracentesis-proven SBP $\left(\geq 250\right.$ neutrophils $\left./ \mathrm{mm}^{3}\right)$, occurring within seven days of hospital admission, met the inclusion criteria. These patients were matched 1:2 (for age, Child-Pugh class and year of admission) with 102 comparable cirrhotic patients with ascites who were admitted for conditions other than SBP.

RESULTS: Patients with SBP had a significantly higher rate of prehospital PPI use $(60.8 \%)$ compared with cirrhotic patients without SBP (42.2\%; $\mathrm{P}=0.03)$. On multivariate analysis, PPI use was the only factor independently associated with SBP (OR 2.09 [95\% CI 1.04 to 4.23]; $\mathrm{P}=0.04)$. Thirty-five (35\%) patients in both groups had no documented indication for PPI use in their charts. Forty-five percent of the remaining cirrhotic patients with SBP had an inappropriate indication, as defined in the protocol, for PPI use compared with $25 \%$ of controls.

CONCLUSIONS: Cirrhotic patients with SBP were twice as likely to have taken PPIs than patients without SBP. These findings reinforce the association between PPI use and SBP observed in other studies. A high percentage of cirrhotic patients were taking a PPI without any documented indication.

Key Words: Ascites; Cirrhosis; Proton pump inhibitor; Spontaneous bacterial peritonitis

Spontaneous bacterial peritonitis (SBP) is a common and severe $\checkmark$ complication in patients with cirrhosis (1), and is associated with significant mortality (2). The initial step in the pathogenesis of SBP is bacterial translocation from the gut flora to mesenteric lymph nodes (1). Increased gut permeability and small intestinal bacterial overgrowth are apparent in liver cirrhosis and both can facilitate bacterial translocation (1,3-5). Cirrhotic patients are more susceptible to infections through different mechanisms including impaired immunity caused by decreased reticuloendothelial system phagocytic activity, complement deficiency and neutrophil dysfunction (6-8).

Gastric acid is a defense mechanism against ingested microorganisms; reduction of gastric acidity increases bacterial proliferation in the stomach and small intestine. This predisposes to enteric infections (9-11). Proton pump inhibitors (PPIs) are potent gastric acid

\author{
L'association entre l'utilisation d'inhibiteurs de la \\ pompe à protons et la péritonite bactérienne spontanée \\ chez des patients cirrhotiques souffrant d'ascite
}

HISTORIQUE : Selon certaines données, il y aurait un lien entre
l'utilisation d'inhibiteurs de la pompe à protons (IPP) et l'apparition
d'une péritonite bactérienne spontanée (PBS) chez les patients cir-
rhotiques souffrant d'ascite. Ces données sont toutefois controversées.
OBJECTIF : Évaluer si l'utilisation d'IPP chez des patients cirrhotiques
souffrant d'ascite s'associe à une augmentation du risque de PBS.
MÉTHODOLOGIE : Les chercheurs ont mené une étude rétrospec-
tive cas-témoins (juin 2004 à juin 2010 ) au Centre hospitalier de
l'Université de Montréal, au Québec. Cinquante et un patients cir-
rhotiques admis à cause d'une PBS démontrée par paracentèse
( $\geq 250$ neutrophiles/mm ${ }^{3}$ ), s'étant manifesté dans les sept jours précé-
dant l'hospitalisation, respectaient les critères d'inclusion. Ces patients
ont été jumelés selon un ratio de $1: 2$ (pour l'âge, le score de Child-
Pugh et l'année d'admission) à 102 patients cirrhotiques souffrant
d'ascite comparables, qui avaient été admis pour d'autres problèmes
qu'une PBS. RÉSULTATS : Les patients ayant une PBS présentaient un taux considérablement plus élevé d'utilisation d'IPP avant l'hospitalisation (60,8\%) que les patients cirrhotiques sans PBS $(42,2 \% ; \mathrm{P}=0,03)$. À l'analyse multivariée, l'utilisation d'IPP était le seul facteur qui s'associait de manière indépendante à la PBS (RR 2,09 [95 \% IC 1,04 à 4,23]; $\mathrm{P}=0,04)$. Dans les deux groupes, 35 patients $(35 \%)$ ne présentaient pas d'indication d'utilisation d'IPP au dossier. Quarante-cinq pour cent des autres patients cirrhotiques ayant une PBS présentaient une indication inappropriée d'utilisation d'IPP selon la définition du protocole, par rapport à $25 \%$ des sujets-témoins.

CONCLUSIONS : Les patients cirrhotiques ayant une PBS étaient deux fois plus susceptibles d'avoir pris des IPP que les patients sans PBS. Ces résultats étayent l'association entre l'utilisation d'IPP et la PBS observée dans d'autres études. Un fort pourcentage de patients cirrhotiques prenaient des IPP sans qu'il y ait d'indication au dossier.

inhibitors and their use has been associated with an increased susceptibility to enteric infections caused by various enteropathogens including Salmonella, Campylobacter and Clostridium difficile $(12,13)$. Furthermore, some data suggest a link between PPI use and the development of SBP in cirrhotic patients with ascites; however, these data are controversial (14-18).

Different mechanisms have been postulated to explain the increased rate of enteric infections associated with PPI therapy. Among these are: increase in small intestinal overgrowth; alteration of the microbial flora; impairment of neutrophil function (in vitro); and delayed gastric emptying (13). Another factor that may influence the infectious risk related to PPI use in advanced cirrhosis is the fact that PPI metabolism may be significantly impaired (with the exception of rabeprazole). This can result in higher exposure to PPIs $(19,20)$.

\footnotetext{
${ }^{1}$ Department of Pharmacy, Centre Hospitalier de l'Université de Montréal; ${ }^{2}$ Université de Montréal; ${ }^{3}$ Division of Hepatology, Department of Medicine,

Hôpital St-Luc, Centre Hospitalier de l'Université de Montréal, Montréal, Québec

Correspondence: Ms Mélissa Ratelle, Department of Pharmacy, Centre Hospitalier de l'Université de Montréal, 3840 St-Urbain, Montréal,

Québec H2W 1T8. Telephone 514-890-8000 ext 14886, fax 514-412-7205, e-mail melissa.ratelle.chum@ssss.gouv.qc.ca

Received for publication July 23, 2013. Accepted April 28, 2014
} 
PPIs are highly effective and well tolerated. They are extensively used and, potentially, overused in many acid-related disorders (21-23). PPI overuse in cirrhotic patients is documented in the literature $(24,25)$.

The primary outcome of our study was to evaluate whether the use of PPIs is associated with the development of SBP in cirrhotic patients with ascites. The secondary outcome was to evaluate whether the indications for PPI use in our study population were appropriate.

\section{METHODS}

Study population and identification of cases and controls

A retrospective review of all consecutive patients admitted between June 2004 and June 2010 with the diagnosis of cirrhosis with ascites according to International Classification of Diseases, Ninth Revision codes was performed at the Centre Hospitalier de l'Université de Montréal, a tertiary care hospital located in Montreal, Quebec. After identification of these patients, the charts were reviewed for the presence or absence of SBP. SBP cases were defined as paracentesis yielding $\geq 250$ polymorphonuclear white blood cells (PMNs) per cubic millilitre with or without a positive culture of ascitic fluid within seven days of admission. Also used was a computerized list of patients with a neutrophil count in their ascitic fluid to ensure that all potential patients were identified. The non-SBP patient group (controls) were cirrhotic patients who underwent diagnostic paracentesis but were negative for SBP (PMN count $<250$ cells $/ \mathrm{mm}^{3}$ and a negative ascitic culture). Patients who had an unreliable medication list on hospital admission, antibiotic use with the exception of metronidazole for treatment of hepatic encephalopathy, immunosuppressant use, gastrointestinal bleeding (within 14 days before hospital admission), HIV infection or previous episode of SBP were excluded. All identified cases were communityacquired SBP. Each SBP patient was then matched according to age, year of admission and Child-Pugh-Turcotte (CPT) class, with two cirrhotic patients with ascites admitted for reasons other than SBP (1:2 ratio).

\section{Recorded information}

Information regarding demographics, reason for hospital admission, cirrhosis etiology, history of variceal bleeding or hepatic encephalopathy, diabetes, CPT classification, Model for End-stage Liver Disease (MELD) score, history of PPI use before admission (indication, dose and duration) and 30-day survival rate was collected. The laboratory blood tests included total bilirubin, albumin, creatinine and sodium levels, and international normalized ratio on admission. Ascitic fluid data included polymorphonuclear neutrophils, protein levels (when available) and bacteriological confirmation of SBP (when available).

\section{PPI use and indication definitions}

Patients were defined as PPI users if they had taken a PPI daily for at least two weeks before hospital admission. Information regarding PPI exposure was retrieved from both physician admission/emergency notes and outpatient medication lists provided by retail pharmacies and/or pharmacist drug history. To assess the duration of and indication for PPI therapy, previous hospitalization medical records were reviewed in addition to outpatient follow-up medical notes because the majority of the authors' patients were already followed by hepatologists at their centre. Appropriate PPI indication was defined as gastroesophageal reflux disease, peptic ulcer disease, Barrett's esophagus, dyspepsia, alcoholic gastritis, Helicobacter pylori infection, and postesophageal variceal sclerotherapy or banding (EVL). Peptic ulcer disease treatment and post-EVL were considered to be inappropriate indications if the treatment duration exceeded three months or two months, respectively.

\section{Statistical analysis}

Non-normally distributed continuous variables are presented as median (quartile 1 to quartile 3). The Wilcoxon Mann-Whitney test was used to compare the two groups. Proportions were used for categorical variables and the Pearson $\chi^{2}$ test (or the Fisher's exact test) was used to the compare the two groups. The relationship between SBP and exposure to PPIs was evaluated using conditional logistic regression (univariate and multivariate) to calculate the ORs. Multivariate analysis was used to measure the potential effect of confounders. The covariates included in the model were sex, diabetes, serum sodium level and MELD score. With regard to the secondary outcome, the percentage of patients receiving a PPI for an appropriate indication was calculated. In all analyses, $\mathrm{P}<0.05$ was considered to be statistically significant. MELD scores were calculated according to the method used by the United Network for Organ Sharing (www. mayoclinic.org).

\section{RESULTS}

A total of 1083 charts from patients with cirrhosis and ascites were reviewed. Paracentesis-proven SBP was confirmed in 242 cases. In all cases, antibiotics were started after the diagnostic paracentesis. From these 242 cases, 72 were excluded because the infection was diagnosed $>7$ days after admission (nosocomial SBP), 19 because they experienced a previous SBP episode, 71 because they were receiving immunosuppressant medication, 22 because of antibiotic use and 14 because of bleeding within 14 days before hospitalization. The remaining 51 cases with community-acquired SBP were then matched according to age, CPT class and year of admission with 102 cirrhotic patients with ascites without SBP. The main reasons for hospital admission in patients without SBP were ascites (32\%), hepatic encephalopathy (13\%), pretransplant evaluation (11\%), alcoholic hepatitis (10\%), acute-onchronic liver failure (7\%) and transjugular intrahepatic portosystemic shunt $(5 \%)$.

The clinical characteristics of the two groups are summarized in Table 1. There were no significant differences in baseline demographics and clinical parameters. The median age was 60 years and the majority of patients were men. The percentage of patients with CPT class C (78\%) and class B (22\%) were similar in the two groups. There was no significant difference in ascitic fluid protein concentration in patients with SBP compared with those without SBP, but data were available from only $67 \%$ and $57 \%$ of patients, respectively.

Among the patients with SBP, the proportion taking PPIs before admission was $61 \%$ compared with $42 \%$ in those without SBP; the difference was significant $(\mathrm{P}=0.03)$ (Table 1$)$. Details of PPI use in the two groups are shown in Table 2. No significant differences were observed for PPI dosage (standard versus double dosing) and overall indications between the two groups. Among documented indications, inappropriate indications for PPI use were found in $45 \%$ of SBP patients (nine of 20 cases) compared with $25 \%$ of patients without SBP (seven of 28 controls) $(\mathrm{P}=0.147)$. No documented indication for PPI use was found in 36\% (11 of 31) of SBP patients compared with $35 \%$ of patients ( 15 of 43 ) without SBP.

On multivariate analysis, PPI use was the only factor independently associated with the occurrence of SBP (OR 2.09 [95\% CI 1.04 to 4.23]; $\mathrm{P}=0.04$ ) (Table 3).

Bacteriological confirmation was available in 26 of 51 (51\%) cases. Gram-positive organisms were found in nine (18\%) patients and Gram-negative organisms were found in 17 (33\%) patients (Table 4). There was no statistical difference in Gram species between PPI users and nonusers. The mortality rate at 30 days was $20 \%$ among patients with SBP and 9\% among patients without SBP, mostly from hepatic failure $(\mathrm{P}=0.057)$.

\section{DISCUSSION}

The results of the current study support an association between PPI use and the development of SBP in cirrhotic patients with ascites. At the time we initiated our study, there were only two published studies that evaluated the relationship between PPI use and SBP in cirrhotic patients as a primary end point but their results were contradictory $(16,18)$. 
TABLE 1

Demographic, clinical and laboratory data from patients with spontaneous bacterial peritonitis (SBP) and controls

\begin{tabular}{|c|c|c|c|}
\hline & \multicolumn{2}{|c|}{ SBP } & \multirow[b]{2}{*}{$\mathbf{P}^{*}$} \\
\hline & Yes $(n=51)$ & No $(n=102)$ & \\
\hline Age, years & $60.2(55.5-69.7)$ & $61.1(52.0-68.1)$ & 0.72 \\
\hline Male sex & $41(80)$ & $73(72)$ & 0.238 \\
\hline Race & & & 0.334 \\
\hline Caucasian & $48(94)$ & $100(98)$ & \\
\hline Other & $3(6)$ & $2(2)$ & \\
\hline $\begin{array}{r}\text { History of hepatic } \\
\text { encephalopathy }\end{array}$ & $23(45)$ & $44(43)$ & 0.818 \\
\hline $\begin{array}{l}\text { History of esophageal } \\
\text { varices }\end{array}$ & $35(69)$ & $62(61)$ & 0.342 \\
\hline $\begin{array}{l}\text { Serum bilirubin at } \\
\text { admission, } \mu \mathrm{mol} / \mathrm{L}\end{array}$ & $66(47-196)$ & $72(49-115)$ & 0.595 \\
\hline $\begin{array}{l}\text { Serum creatinine at } \\
\text { admission, } \mu \mathrm{mol} / \mathrm{L}\end{array}$ & $98(70-133)$ & $100(66-124)$ & 0.392 \\
\hline $\begin{array}{l}\text { Serum sodium at } \\
\text { admission, } \mathrm{mmol} / \mathrm{L}\end{array}$ & $\begin{array}{c}133(129-136) \\
n=34\end{array}$ & $\begin{array}{c}134(129-136) \\
n=58\end{array}$ & 0.668 \\
\hline Ascites protein, g/L & $12(5-20)$ & $8.5(5-14)$ & 0.238 \\
\hline Etiology of cirrhosis & & & 0.491 \\
\hline Alcohol & $25(49)$ & $44(43)$ & \\
\hline $\mathrm{HCV} / \mathrm{HBV}$ & $14(28)$ & $27(27)$ & \\
\hline NASH/cryptogenic & $8(16)$ & $26(26)$ & \\
\hline Other & $4(8)$ & $5(5)$ & \\
\hline Diabetes mellitus & $16(31)$ & $33(32)$ & 0.903 \\
\hline Child-Pugh score & $11(10-12)$ & $10(10-11)$ & 0.352 \\
\hline MELD score & $21(17-27)$ & $20(16-23)$ & 0.112 \\
\hline PPI use & $31(61)$ & $43(42)$ & 0.03 \\
\hline
\end{tabular}

Data presented as median (quartile 1-quartile 3) or $n$ (\%) unless otherwise indicated. ${ }^{*} P<0.05$ considered to be statistically significant. HBV Hepatitis $B$ virus; HCV Hepatitis C virus; MELD Model for End-stage Liver Disease; NASH Nonalcoholic steatohepatitis; PPI Proton pump inhibitor

TABLE 2

Details of proton pump inhibitor (PPI) use

\begin{tabular}{lccc}
\hline & \multicolumn{2}{c}{ Spontaneous bacterial peritonitis } & \\
\cline { 2 - 3 } & Yes $(\mathbf{n}=\mathbf{5 1})$ & No $(\mathbf{n}=\mathbf{1 0 2})$ & $\mathbf{P}$ \\
\hline Double daily PPI dosing & $6(19) ; \mathrm{n}=31$ & $14(33) ; \mathrm{n}=43$ & 0.207 \\
PPI-appropriate indications & $11(55) ; \mathrm{n}=20$ & $21(75) ; \mathrm{n}=28$ & 0.147 \\
Indications & $\mathrm{n}=31$ & $\mathrm{n}=43$ & 0.746 \\
Postesophageal variceal & $6(19)$ & $7(16)$ & \\
$\quad$ banding & & & \\
Peptic ulcer disease & $7(23)$ & $3(7)$ & \\
Dyspepsia & $2(7)$ & $6(14)$ & \\
GERD & $1(3)$ & $3(7)$ & \\
Alcoholic gastritis & $1(3)$ & $2(5)$ & \\
Helicobacter pylori & $1(3)$ & $2(5)$ & \\
Gastroprotection & $1(3)$ & $3(7)$ & \\
Other & $1(3)$ & $2(5)$ & \\
No documentation & $11(36)$ & $15(35)$ & \\
\hline
\end{tabular}

Data presented as $n$ (\%) unless otherwise indicated. All patients were taking PPIs (daily versus twice daily) for at least 30 days. Inappropriate use was considered if peptic ulcer disease treatment $>3$ months, postesophageal variceal banding prophylaxis $>2$ months, portal hypertension gastritis and ulcer prophylaxis without proper indication. GERD Gastroesophageal reflux disease

First, Campbell et al (16) did not find an association between PPI use and SPB in a retrospective case-control study involving 116 consecutive cirrhotic patients with ascites (OR 1.22 [95\% CI 0.52 to 2.87]; $\mathrm{P}=0.64$ ). However, limitations of their study included the small number of patients with SBP (32 of 116) and the fact that the MELD score was significantly higher in the SBP group $(\mathrm{P}=0.002)$.
TABLE 3

Risk factors for spontaneous bacterial peritonitis

\begin{tabular}{lcc}
\hline & OR $(95 \% \mathrm{CI})$ & $\mathbf{P}$ \\
\hline Univariate analysis & & \\
$\quad$ Proton pump inhibitor use & $2.12(1.07-4.19)$ & 0.032 \\
Multivariate analysis & & \\
Proton pump inhibitor use & $2.14(1.07-4.14)$ & 0.04 \\
Male sex & $1.56(0.67-3.67)$ & 0.304 \\
Diabetes mellitus & $0.93(0.44-1.97)$ & 0.844 \\
Serum sodium level & $0.98(0.92-1.05)$ & 0.518 \\
Model for End-stage Liver Disease score & $1.05(0.99-1.11)$ & 0.055 \\
\hline
\end{tabular}

\section{TABLE 4}

Bacteriological confirmation in patients with spontaneous bacterial peritonitis $(n=26)$

\begin{tabular}{ll}
\hline & $\mathbf{n}$ \\
\hline Gram positive & 6 \\
Staphyloccocus species & 3 \\
Streptoccocus species & \\
Gram negative & 7 \\
Escherichia coli & 4 \\
Klebsiella species & 2 \\
Enterobacter species & 1 \\
Haemophilus influenza & 1 \\
Campylobacter fetus & 1 \\
Pseudomonas aeruginosa & 1 \\
Bacteroides fragilis & \\
\hline
\end{tabular}

Then, in 2009, Bajaj et al (18) performed a retrospective case-control study involving 70 patients with SBP matched 1:1 for age and CPT class with 70 comparable patients with cirrhosis and ascites. There was no significant difference in the CPT score and the MELD score between the two groups. On multivariate analysis, PPI use was independently associated with SBP (OR 4.31 [95\% CI 1.34 to 11.7]; $\mathrm{P}=0.003$ ) and ascitic fluid protein concentration was protective.

Since then, three other retrospective case-control studies involving cirrhotic patients with ascites have been published with the same primary end point $(14,15,26)$. Choi et al $(15)$ compared 83 patients with SBP with 93 controls who did not have SBP. On multivariate analysis, CPT class C, high MELD score and PPI use (OR 3.44 [95\% CI 1.164 to 10.188 ]; $\mathrm{P}=0.025$ ) were independent risk factors for SBP. $\mathrm{H}_{2}$ receptor antogonist use was not associated with SBP. Goel et al (14) compared 65 cirrhotic patients with SBP with 65 patients without SBP. The CPT score was significantly higher in the SBP group ( $\mathrm{P}=0.046)$. In the multivariate analysis, after adjusting for CPT score, patients who did not use PPI in the previous 90 days were $71 \%$ less likely to develop SBP than those who used PPI in the previous seven days ( $\mathrm{OR} 0.29$ [95\% CI 0.13 to 0.68]; $\mathrm{P}=0.004$ ). In this study, patients who received previous antibiotics were not excluded because it was performed in the previously described studies, but the authors believed that it did not influence their results. Finally, de Vos et al (26) compared 51 unmatched cirrhotic patients with SBP with 51 cirrhotic patients without SBP. The study showed that cirrhotic patients with SBP received PPIs twice as often as noninfected cirrhotic patients with ascites; however, in the multivariate analysis, PPI use was not associated with SBP $(\mathrm{P}=0.1)$. The only parameter significantly associated with SBP was international normalized ratio $(\mathrm{P}=0.007)$.

A recent meta-analysis including eight studies $(\mathrm{n}=3815)$ (27) showed that cirrhotic patients receiving a PPI had approximately three times the risk of developing SBP compared with patients not receiving PPIs (OR 3.15 [95\% CI 2.09 to 4.74]). The five studies discussed above were included in the meta-analysis plus two retrospective cohort studies available as abstracts $(28,29)$ and one prospective cohort study (30). 
The methodology used in our study was very similar to the study by Bajaj et al (18). We matched cases and controls for age and CPT class, the latter factor being very important because the severity of the disease is associated with a greater risk for developing SBP. We also considered the potential bias of time on PPI prescribing habits by matching cases and controls according to year of admission. We hypothesized that if there was a change in PPI prescribing habits over the years, both groups would be affected equally. Confounding factors, such as previous gastrointestinal bleeding, SBP episode(s), or antibiotic or immunosuppressant use, were excluded. Due to our stringent inclusion and exclusion criteria, we were not able to recruit more than 51 cases, but we found two controls per SBP case. Because paracentesis is not performed routinely on admission in cirrhotic patients with ascites at our centre, it was difficult to recruit more than two controls for every case of SBP.

On multivariate analysis, PPI use was the only factor independently associated with SBP (OR 2.09 [95\% CI 1.04 to 4.23]; $\mathrm{P}=0.04$ ). MELD score was found to have a nonsignificant effect (OR 1.05 [95\% CI 0.99 to 1.11]; $\mathrm{P}=0.06$ ). It would have been interesting to know whether ascitic fluid protein concentration was protective against SBP but no conclusion can be drawn because data were missing for nearly $40 \%$ of the patients in both groups. These missing data could be explained by the fact that radiologists frequently perform parencentesis in our centre and they do not request ascitic fluid concentration routinely.

The secondary outcome of our study was to evaluate whether the indications for PPI use in the study population were appropriate. The results show, as in previous observations, an overuse of PPI in cirrhotic patients $(24,25)$. The fact that $35 \%$ of patients with SBP and $36 \%$ of patients without SBP received a PPI without any documented indication is concerning. In addition, only $55 \%$ and $75 \%$ of SBP cases and controls, respectively, received a PPI for an appropriate indication as defined in our study.

It is a common practice to prescribe a PPIs after esophageal variceal sclerotherapy or banding to prevent or heal postprocedure ulcerations. Some data from uncontrolled nonrandomized studies showed that PPIs may have a role in the prevention and healing of ulcerations

\section{REFERENCES}

1. Gines P, Arroyo V, Rodes J. Pathophysiology, complications, and treatment of ascites. Clin Liver Dis 1997;1:129-55.

2. Pinzello G, Simonetti RG, Craxi A, Di Piazza S, Spano C, Pagliaro L. Spontaneous bacterial peritonitis: A prospective investigation in predominantly nonalcoholic cirrhotic patients. Hepatology 1983;34:545-9.

3. Scarpellini E, Valenza V, Gabrielli M, et al. Intestinal permeability in cirrhotic patients with and without spontaneous bacterial peritonitis: Is the ring closed? Am J Gastroenterol 2010;105:323-7.

4. Jun DW, Kim KT, Lee OY, et al. Association between small intestinal bacterial overgrowth and peripheral bacterial DNA in cirrhotic patients. Dig Dis Sci 2010;55:1465-71.

5. Chang CS, Chen CH, Lien HC, Yeh HZ. Small intestine dysmotility and bacterial overgrowth in cirrhotic patients with spontaneous bacterial peritonitis. Hepatology 1998;28:1187-90.

6. Such J, Guarner C, Enriquez J, Rodriguez JL, Seres I, Vilardell F Low $\mathrm{C} 3$ in cirrhotic ascites predisposes to spontaneous bacterial peritonitis. J Hepatol 1988;6:80-4.

7. Rimola A, Soto R, Bory F, Arroyo V, Piera C, Rodes J. Reticuloendothelial system phagocytic activity in cirrhosis and its relation to bacterial infections and prognosis. Hepatology 1984:4:53-8.

8. Fiuza C, Salcedo M, Clemente G, Tellado J. In vivo neutrophil dysfunction in cirrhotic patients with advanced liver disease. J Infect Dis 2000;182:526-33.

9. Martinsen TC, Bergh K, Waldum HL. Gastric juice: A barrier against infectious diseases. Basic Clin Pharmacol Toxicol 2005;96:94-102.

10. Hunt RH. The protective role of gastric acid. Scand J Gastroenterol (Suppl) 1988;146:34-9. postesophageal sclerotherapy (31). In a double-blinded randomized placebo-controlled trial, the short-term use of pantoprazole (10 days) after elective band ligation was associated with a significant reduction of the size of ulcers but had no effect on the overall number of ulcers or in symptoms related to the procedure (32). In our study, PPI use post-EVL was considered to be appropriate if used for $\leq 2$ months postvariceal ligation. Even with this broad definition, we observed that PPI use was pursued for longer periods post-EVL without medical or pharmacological reason.

One of the strengths of our study was the fact that we used two reliable sources to document PPI use. The medication list documented by physician notes and a complete medication list copy provided by retail pharmacies or hospital pharmacist drug history were considered to be trustworthy. Because PPIs are not available over the counter in Canada, it was easier to evaluate the duration of use. In our opinion, all patients taking PPIs for at least 30 days before admisson better reflects PPI use than the minimum of 14 days that was initially defined in our protocol.

\section{CONCLUSION}

Our study has shown that PPI use in cirrhotic patients with ascites is an independent risk factor for developing SBP. Our data reinforce the previous positive link between PPI use and SBP observed in other retrospective case-control studies. Ideally, a prospective randomized study should be conducted; however, such a study would be difficult to perform and ethically questionable. In the meantime, PPI indications in cirrhotic patients should be frequently re-evaluated with particular attention devoted to duration of use, especially following EVL. The minimal effective PPI dose should be used in advanced cirrhosis because it is known that PPI exposure is increased in these patients because of an altered pharmacokinetic profile. The double-standard dose should also be avoided whenever possible.

DISCLOSURES: The authors have no financial disclosures or conflicts of interest to declare.
11. Giannella RA, Broitman SA, Zamcheck N. Gastric acid barrier to ingested microorganisms in man: Studies in vivo and in vitro. Gut 1972;13:251-6.

12. Leonard J, Marshall JK, Moayyedi P. Systematic review of the risk of enteric infection in patients taking acid suppression. Am J Gastroenterol 2007;102:2047-56.

13. Bavishi C, Dupont HL. Systematic review: The use of proton pump inhibitors and increased susceptibility to enteric infection. Aliment Pharmacol Ther 2011;34:1269-81.

14. Goel GA, Deshpande A, Lopez R, Hall GS, van Duin D, Carey WD. Increased rate of spontaneous bacterial peritonitis among cirrhotic patients receiving pharmacologic acid suppression. Clin Gastroenterol Hepatol 2012;10:422-7.

15. Choi EJ, Lee HJ, Kim KO, et al. Association between acid suppressive therapy and spontaneous bacterial peritonitis in cirrhotic patients with ascites. Scand J Gastroenterol 2011;46:616-20.

16. Campbell MS, Obstein K, Reddy KR, Yang YX. Association between proton pump inhibitor use and spontaneous bacterial peritonitis. Dig Dis Sci 2008;53:394-8.

17. Bauer TM, Steinbruckner B, Brinkmann F, et al. Small intestinal bacterial overgrowth in patients with cirrhosis: Prevalence and relation with spontaneous bacterial peritonitis. Am J Gastroenterol 2001;96:2962-7.

18. Bajaj JS, Zadvornova Y, Heuman DM, et al. Association of proton pump inhibitor therapy with spontaneous bacterial peritonitis in cirrhotic patients with ascites. Am J Gastroenterol 2009;104:1130-4.

19. Robinson M, Horn J. Clinical pharmacology of proton pump inhibitors: What the practising physician needs to know. Drugs 2003;63:2739-54.

20. Branch RA. Drugs in liver disease. Clin Pharmacol Ther 1998;64:462-5. 
21. Naunton M, Peterson GM, Bleasel MD. Overuse of proton pump inhibitors. J Clin Pharm Ther 2000;25:333-40.

22. Heidelbaugh JJ, Kim AH, Crang R, Walker PC. Overutilization of proton-pump inhibitors: What the clinician needs to know. Ther Adv Gastroenterol 2012;5:219-32.

23. Heidelbaugh JJ, Goldberg KL, Inadomi JM. Overutilization of proton pump inhibitors: A review of cost-effectiveness and risk in PPI. Am J Gastroenterol 2009;104:S27-32.

24. Kalaitzakis E, Bjornsson E. Inadequate use of proton-pump inhibitors in patients with liver cirrhosis. Eur J Gastroenterol Hepatol 2008;20:512-8.

25. Chavez-Tapia NC, Tellez-Avila FI, Garcia-Leiva J, Valdovinos MA. Use and overuse of proton pump inhibitors in cirrhotic patients. Med Sci Monit 2008;14:468-72.

26. de Vos M, De Vroey B, Garcia Garcia B, et al. Role of proton pump inhibitors in the occurrence and the prognosis of spontaneous bacterial peritonitis in cirrhotic patients with ascites. Liver Int 2013;33:1316-23.

27. Deshpande A, Pasupuleti V, Thota P. Acid-suppressive therapy is associated with spontaneous bacterial peritonitis in cirrhotic patients: A meta-analysis. J Gastroenterol Hepatol 2013;28:235-42.
28. Northup PG, Argo CL, Berg CL. Chronic proton pump inhibitor use is strongly associated with hepatorenal syndrome and spontaneous bacterial peritonitis in cirrhosis patients. Hepatology 2008;48:325A.

29. Bulsiewicz W, Scherer JR, Feinglass JM, Howden CW, Flam SL. Proton pump inhibitor (PPI) use is independently associated with spontaneous bacterial peritonitis (SBP) in cirrhotics with ascites. Gastroenterology 2009;136:A-11. (Abst)

30. van Vlerken LG, Huisman EJ, van Hoek B, et al. Bacterial infections in cirrhosis: Role of proton pump inhibitors and intestinal permeability. Eur J Clin Invest 2012;42:760-7.

31. Lodato F, Azzaroli F, Di Girolamo M, et al. Proton pump inhibitors in cirrhosis: Tradition or evidence based practice?

World J Gastroenterol 2008;14:2980-5.

32. Shaheen NJ, Stuart E, Schmitz SM, et al. Pantoprazole reduces the size of postbanding ulcers after variceal band ligation: A randomized, controlled trial. Hepatology 2005;41:588-94. 


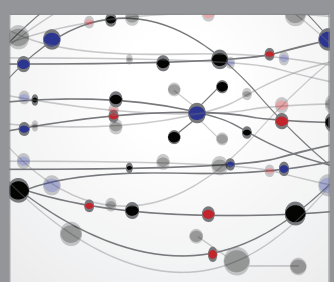

The Scientific World Journal
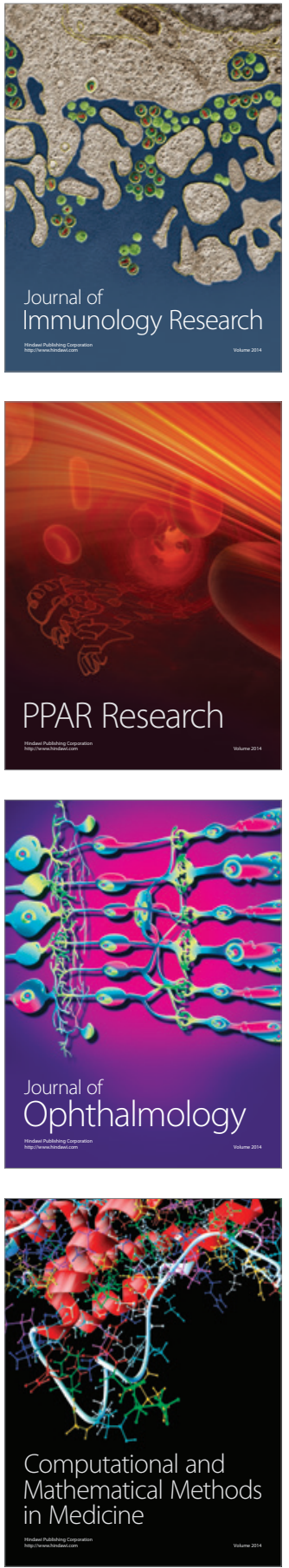

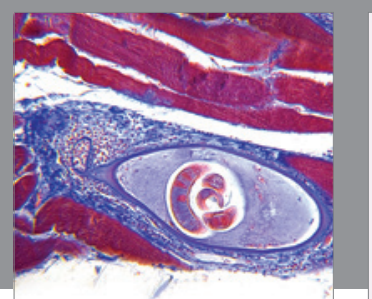

Gastroenterology Research and Practice

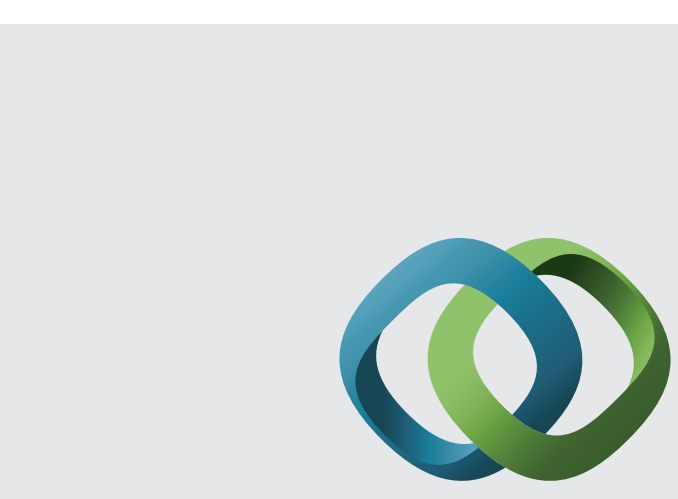

\section{Hindawi}

Submit your manuscripts at

http://www.hindawi.com
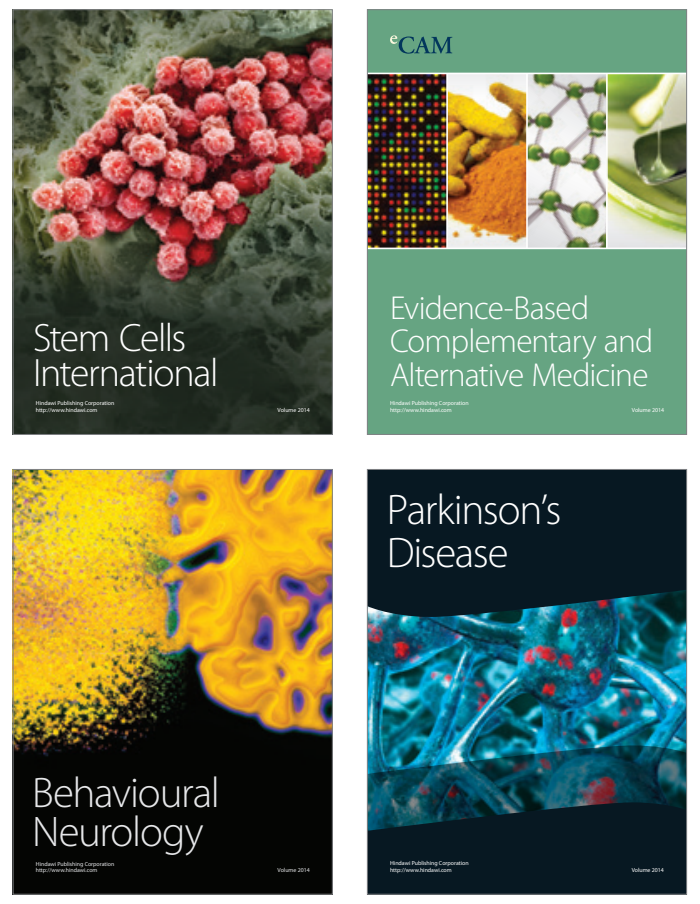
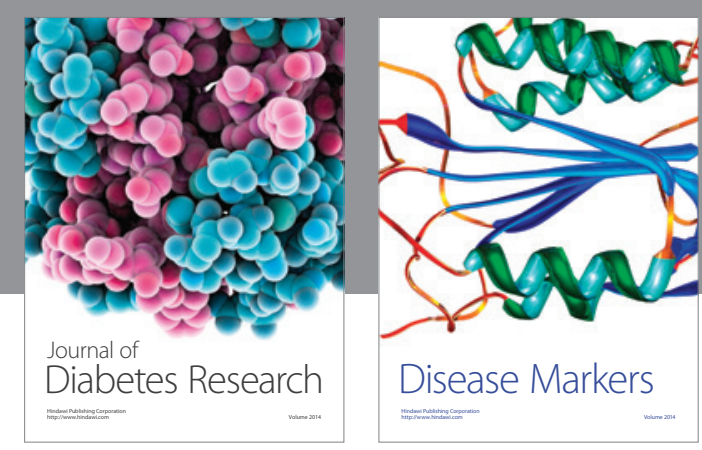

Disease Markers
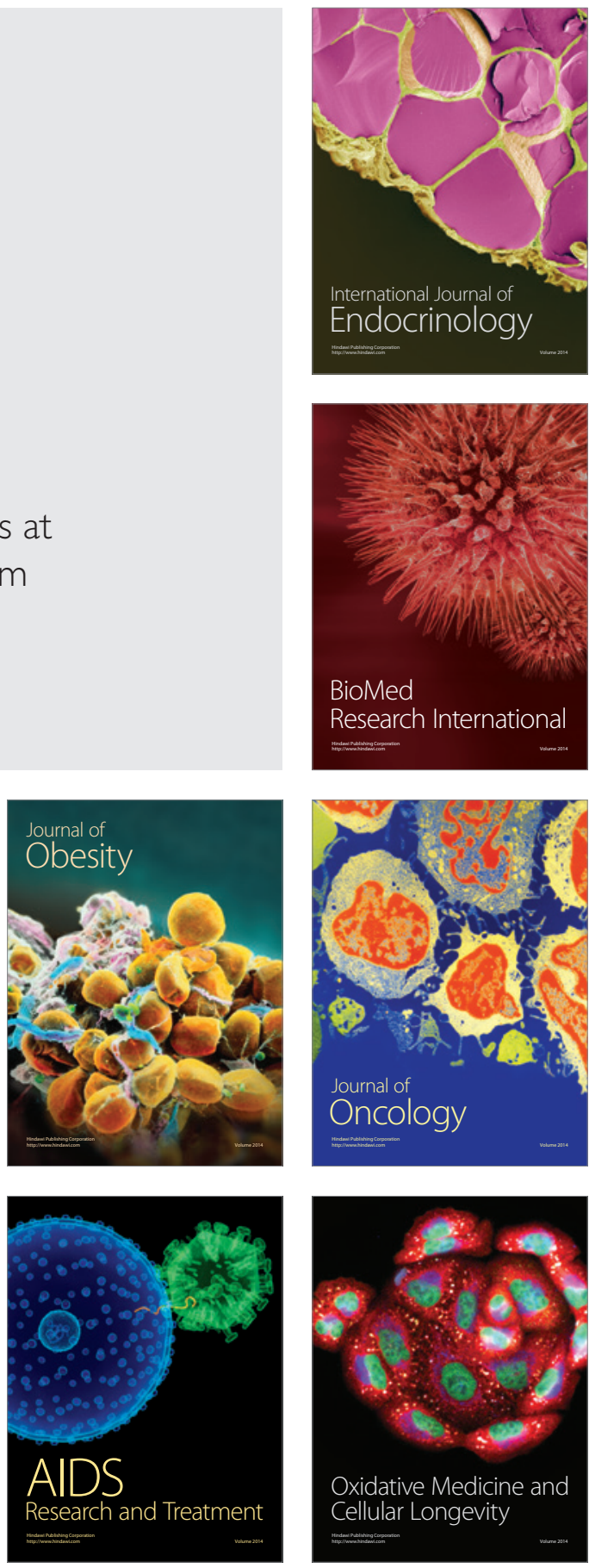